\title{
Media Pembelajaran Berbasis Realistic Mathematics Education Berbantukan Adobe Flash di Masa Pandemi Covid-19
}

\author{
Murtafiah*1, St. Inaya Masrura $^{2}$, Saharuddin $^{3}$ \\ ${ }^{1,2,3}$ Universitas Sulawesi Barat \\ e-mail: *11 murtafiah@ unsulbar.ac.id, ${ }^{2}$ sittiinayamasrura@ @unsulbar.ac.id, ${ }^{3}$ saharuddints838@ gmail.com
}

\begin{abstract}
Abstrak
Penelitian ini bertujuan untuk mengembangkan media pembelajaran matematika berbasis Realistic Mathematics Education (RME) dengan bantuan Adobe Flash yang memenuhi kriteria valid, praktis, dan efektif. Media pembelajaran ini diharapkan mampu mendukung pembelajaran di masa pandemi covid-19. Penelitian ini merupakan penelitian pengembangan dengan menggunakan model ADDIE. Langkah-langkah dalam penelitian ini meliputi: (1) analisis, (2) perencanaan, (3) pengembangan, (4) implementasi, dan (5) evaluasi. Instrumen yang digunakan dalam mengumpulkan data antara lain lembar validasi, angket respon siswa dan guru, dan tes hasil belajar. Hasil penelitian menunjukkan bahwamedia pembelajaran matematika berbasis Realistic Mathematics Education (RME) dengan bantuan Adobe Flash memenuhi kriteria valid berdasarkan penilaian oleh dua orang pakar dengan skor rata-rata 3,5, memenuhi kriteri praktis berdasarkan penilai guru, dan memenuhi kriteria efektif berdasarkan skor hasil belajar siswa serta respon siswa yang sangat positif. Berdasarkan hasil tersebut, media pembelajaran matematika berbasis Realistic Mathematics Education (RME) dengan bantuan Adobe Flash memenuhi kalayakan sehingga dapat digunakan dalam pembelajaran.
\end{abstract}

Kata Kunci: Pengembangan Media, RME, Adobe Flash.

\section{PENDAHULUAN}

Wabah covid-19 tidak hanya melanda Indonesia tetapi juga melanda hampir seluruh negara di dunia. Wabah ini berdampak di semua sektor kehidupan, termasuk di bidang pendidikan. Sejak virus ini masuk di Indonesia, pemerintah mengambil kebijakan untuk mengalihkan pembelajaran tatap muka yang dilaksanakan di sekolah menjadi pembelajaran jarak jauh atau biasa disebut pembelajaran daring untuk menghindari penularan virus ini. Pembelajaran daring menjadi tantangan tersendiri baik bagi peserta didik maupun bagi pendidik khususnya dalam pembelajaran matematika.

Matematika merupakan disiplin ilmu yang mempelajari tentang sistem-sistem abstrak yang terbentuk berdasarakan elemen-elemen abstrak pula dan elemen-elemen tersebut tidak dapat digambarkan dalam alur atau pola yang konkrit. Lebih jauh, Saputri (2021) menatakan bahwa dalam pembelajaran matematika dituntut kegiatan mental yang relatif tinggi, oleh karena itu siswa harus senantiasa berpartisipasi aktif dalam pembelajaran.

Salah satu permasalahan yang dihadapi oleh peserta didik selama pembelajaran daring adalah peserta didik kesulitan memahami materi. Salah satu penyebabnya antara lain karena guru tidak dapat menjelaskan secara langsung materi tersebut. Sebagian besar guru hanya memberikan materi berupa teks dalam buku paket siswa. Hal ini berdampak pada rendahnya hasil belajar matematika siswa. Agar tujuan pembelajaran dapat tercapai, guru dituntut untuk dapat mendesain dan menggunakan media pembelajaran yang tepat.

Penggunaan pendekatan pembelajaran yang baik dapat mendukung keberhasilan peserta didik dalam belajar. Menurut Huda (2018) pendekatan pembelajaran adalah cara-cara yang ditempuh oleh seorang pembelajar untuk bisa belajar dengan efektif. Salah satu pendekatan yang dapat membuat pembelajaran menjadi efektif adalah pendekatan Realistic Mathematics Education (RME). Menurut Tandiling (2010), konsep RME sejalan dengan kebutuhan untuk memperbaiki pendidikan matematika di Indonesia dalam hal mengatasi persoalan bagaimana meningkatkan pemahamann siswa mengenai matematika. Salah satu manfaat dari pendekatan realistik adalah dapat membuat matematika lebih menarik, tidak terlalu formal, dan tidak terlalu abstrak. Agar matematika bisa tampak lebih nyata dan lebih menarik lagi maka diperlukan media pembelajaran yang relevan dengan pendekatan realistik tersebut. Selain dari penggunaan pendekatan

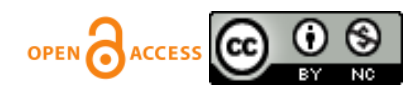


tersebut, hal yang tidak kalah penting dari itu adalah penggunaan media dalam pembelajaran yang juga dapat mendukung keberhasilan peserta didik dalam belajar. Media yang digunakan dalam proses pembelajaran biasanya disebut media pembelajaran.

Media pembelajaran merupakan media informasi kegiatan belajar mengajar sehingga mampu memberikan efektifitas dan interaktivitas dalam pembelajaran. Adanya media pada proses belajar mengajar, diharapkan dapat membantu guru dalam pembelajaran lebih visual, interaktif, menarik, mudah dan cepat dimengerti (Wibowo, 2013). Berdasarkan pernyataan di atas media yang dapat digunakan dalam pembelajaran adalah media berbasis adobe flash. Adobe flash adalah salah satu perangkat lunak dari komputer yang dapat mendesain gambar, video, animasi, dan efek lainnya. Karena kelebihannya adobe flash ini telah digunakan dalam merancang program pembelajaran berbasis komputer seperti kemampuannya menggabungkan kemampuan animasi huruf dan gambar yang menarik, animasi dan huruf terlihat bagus pada ukuran windows dan revolusi layar berapapun, kecepatan gambar, animasi atau huruf yang akan ditampilkan (muncul) dapat diatur kecepatannya serta dilengkapi dengan fasilitas tombol untuk dapat berpindah dari satu bagian kebagian lainnya (Supriyadi, 2016).

Berdasarkan apa yang dipaparkan di atas menunjukkan bahwa Realistic Mathematics Education (RME) ternyata sejalan dengan penggunaan aplikasi adobe flash yang dapat menghadirkan teks, gambar, animasi sederhana, video atau efek khusus lainnya, sehingga media pembelajaran dapat terlihat lebih menarik, dan tampak lebih nyata. Media pembelajaran dan pendekatan yang cocok atau bervariasi dibutuhkan dalam pembelajaran, gurupun dituntut untuk mampu menggunakan berbagai media pembelajaran sehingga proses belajar mengajar dapat berjalan dengan baik, dan lancar.

\section{METODE PENELITIAN}

Jenis penelitian yang digunakan dalam penelitian ini adalah jenis penelitian dan pengembangan (Research \& Development). Model pengembangan yang digunakan dalam penelitian ini adalah model pengembangan ADDIE yang meliputi lima tahapan, antara lain: (1) Analyze untuk mendapatkan gambaran terkait dengan studi lapangan dan teori yang akan digunakan dalam mendesain media pembelajaran; (2) Design yang merupakan tahapan untuk merancang prototype awal media pembelajaran; (3) Development merupakan tahapan untuk mengukur kevalidan media pembelajaran (4) Implementation merupakan tahapan uji coba untuk mengukur kepraktisan dan keefektifan media pembelajaran, dan (5) Evaluation bertujuan untuk untuk memberi umpan balik kepada pihak pengguna media. Instrumen yang digunakan dalam penelitian ini adalah lembar validasi untuk media pembelajaran, lembar penilaian guru, lembar angket respon siswa, serta Lembar Tes Hasil Belajar.

Data yang telah dikumpulkan selanjutnya dianalisis untuk mengetahui kevalidan, keefektifan, dan kepraktisan media pembelajaran yang telah dikembagkan. Adapun analisis yang digunakan antara lain:

1. Analisis kevalidan

Skor rata-rata penilaian terhadap media pembelajaran diperoleh dengan rumus:

Skor rata-rata $=\frac{\text { skot total }}{\text { banyak butir }}$

Skor rata-rata keseluruhan $=\frac{\text { jumlah skor rata-rata }}{\text { banyak aspek }}$

Selanjutnya skor tersebut dikonversi berdasarkan kriteria kevalidan pada Tabel 1 berikut:

Tabel 1. Kriteria kevalidan media pembelajaran

\begin{tabular}{|c|c|}
\hline Interval skor & Kriteria \\
\hline $\mathrm{x}>3,4$ & Sangat valid \\
\hline $2,8<\mathrm{x} \leq 3,4$ & Valid \\
\hline $2,2<\mathrm{x} \leq 2,8$ & Cukup Valid \\
\hline $1,6<\mathrm{x} \leq 2,2$ & Kurang Valid \\
\hline $\mathrm{x} \leq 1,6$ & Tidak Valid \\
\hline
\end{tabular}


Media pembelajaran yang dikembangkan dikatakan valid apabila rata-rata hasil dari validasi kedua validator memenuhi kriteria kevalidan minimal sampai ke valid.

\section{Analisis kepraktisan}

Analisis data kepraktisan dilakukan terhadap data penilaian guru dan respon siswa dengan menggunakan rumus:

Skor rata-rata penilaian guru $=\frac{\text { skor total }}{\text { banyak butir }}$

Respon Siswa $=\frac{\text { banyak siswa yang merespon positif }}{\text { banyak siswa di kelas }} \times 100 \%$

Adapun persentasi respon siswa dapat dilihat pada tabel 2 berikut:

Tabel 2. kriteria Penilaian Angket Respon Siswa

\begin{tabular}{|c|c|}
\hline Persentase Respon Siswa (\%) & Kriteria \\
\hline Rs $\geq 85$ & Sangat positif \\
\hline $70 \leq \mathrm{Rs}<85$ & Positif \\
\hline $50<\mathrm{Rs} \leq 70$ & Kurang positif \\
\hline $\mathrm{Rs}<50$ & Tidak positif \\
\hline
\end{tabular}

Kepraktisan media yang dikembangkan dapat dilihat dengan memperhatikan kriteria kepraktisan media yang telah ditetapkan. Media pembelajaran dikatakan praktis apabila memenuhi kriteria kepraktisan minimal adalah praktis untuk penilaian guru dan positif untuk respon siswa.

\section{Analisis Keefektifan}

Analisis data keefektifan diperoleh dari data hasil belajar siswa setelah menggunakan media diolah untuk mengetahui efektifnya media pembelajaran yang dikembangkan.

Tabel 3. Kriteria Penilaian Kemampuan Akademik

\begin{tabular}{|c|c|}
\hline Persentase Ketuntasan (\%) & Kriteria \\
\hline$K>80$ & Sangat tinggi \\
\hline $60<K \leq 80$ & Tinggi \\
\hline $40<K \leq 60$ & Cukup \\
\hline $20<K \leq 40$ & Rendah \\
\hline$K \leq 20$ & Sangat rendah \\
\hline
\end{tabular}

Media pembelajaran dikatakan efektif jika memenuhi kriteria minimal tinggi.

\section{HASIL DAN PEMBAHASAN}

Dari hasil pengembangan media pembelajaran ini, telah dilakukan beberapa tahapan berdasarkan model pengembangan ADDIE. Berikut disajikan hasil penelitian yang diperoleh dari setiap tahapan. Analisis dilakukan sebelum merancang media pembelajaran. Pada tahap ini telah dilakukan analisis mengenai apa-apa yang dibutuhkan dalam pengembangan media pembelajaran melalui studi lapang dan studi pustaka. Studi lapangan dilakukan di MAN Majene. Berdasarkan hasil studi lapangan diketahui bahwa pembelajaran matematika selama masa pandemi dilakukan secara daring dimana guru memberikan materi berupa teks kepada siswa, sehingga siswa mengalami kesulitan dalam memahami materi matematika yang sifatnya abstrak. Berdasarkan identifikasi materi yang dilakukan peneliti melalui studi pustaka, maka ditentukan materi yang akan disajikan dalam media pembelajaran adalah materi transformasi yang meliputi translasi dan refleksi. Selain itu, ditentukan pula kompetensi dasar, indikator, dan tujuan pembelajarannya. 
Berdasarkan hasil yang diperoleh dari tahapan analisis, selanjutnya peneliti merancang media pembelajaran. Tampilan media pembelajaran yang dirancang oleh peneliti dapat dilihat pada gambar di bawah:

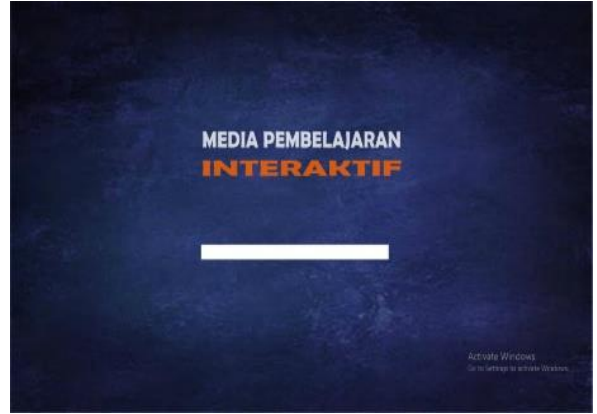

Rancangan halaman pembuka

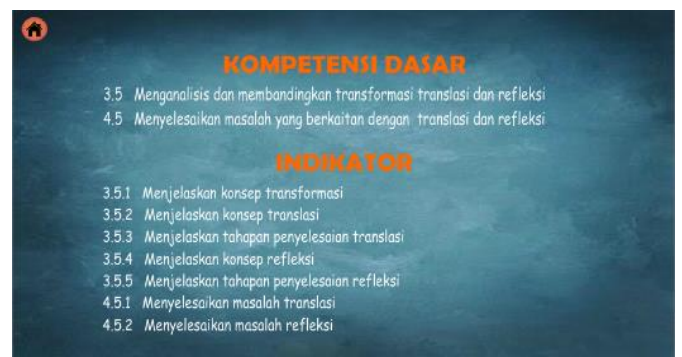

Rancangan halaman KD dan indikator

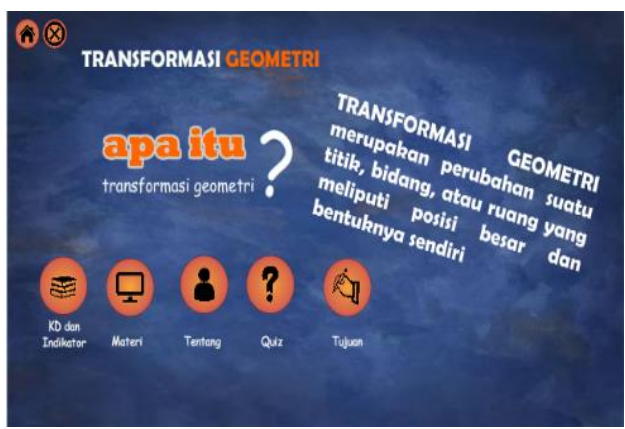

Rancangan halaman menu utama

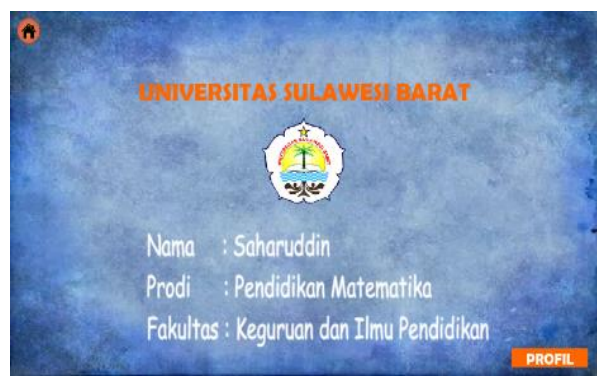

Rancangan halaman profil

Gambar 1. Rancangan Awal Media Pembelajaran

Setelah media pembelajaran dirancang, selanjutnya dilakukan penilaian kevalidan. Penilaian dilakukan oleh dua orang pakar. Hasil validasi terhadap media pembelajaran dari kedua validator disajikan pada Tabel 4.

Tabel 4. Hasil Validasi Lembar Validasi Media Pembelajaran

\begin{tabular}{|l|c|c|c|}
\hline Aspek Penilaian & Validator 1 & Validator 2 & Rata-rata \\
\hline Format & 8 & 6 & 7 \\
\hline Bahasa & 7 & 6 & 6,5 \\
\hline Petunjuk & 7 & 6 & 6,5 \\
\hline Isi & 12 & 9 & 10,5 \\
\hline \multicolumn{3}{|c|}{ Skor rata-rata } & 3,3 \\
\hline
\end{tabular}

Dari Tabel 4 di atas, diperoleh skor rata-rata sebesar 3,3 yang berada dalam kategori valid. Berdasarkan kriteria kevalidan disimpulkan bahwa media pembelajaran yang telah dikembangan dinyatakan valid dan dapat digunakan dalam tahapan implementasi. Walaupun media pembelajaran dinyatakan valid, ada beberapa perbaikan yang dilakukan oleh peneliti berdasarkan saran dan masukan dari kedua validator, diantaranya adalah menambahkan latihan yang mirip dengan evaluasi sebelum dilakukan evaluasi dan Menambahkan soal dalam bentuk gambar untuk setiap indikator.

Setelah media pembelajaran dinyatakan valid, selanjutnya dilakukan uji coba terhadap media tersebut. Uji coba dilakukan secara terbatas pada siswa MAN 1 Majene. Dari tahapan implementasi ini, diperoleh hasil kepraktisan dan keefektifan media pembelajaran. Uji kepraktisan dilakukan terhadap data hasil penilaian guru dan data hasil angket respon siswa. Hasil penilaian guru matematika terhadap media pembelajaran disajikan pada Tabel 5 berikut: 
https://jurnal.unsulbar.ac.id/index.php/saintifik

Tabel 5. Hasil penilaian media pembelajaran

\begin{tabular}{|l|c|c|}
\hline \multicolumn{1}{|c|}{ Butir } & Skor & Kriteria \\
\hline Bahasa yang digunakan mudah dipahami & 4 & Baik \\
\hline $\begin{array}{l}\text { Kesesuaian media } \text { adobe flash dengan } \\
\text { kemampuan peserta didik }\end{array}$ & 3 & Cukup baik \\
\hline Kejelasan tulisan untuk dibaca & 4 & Baik \\
\hline Kejelasan urutan materi & 4 & Baik \\
\hline Kejelasan isi materi & 4 & Baik \\
\hline Kejelasan tujuan pembelajaran & 4 & Baik \\
\hline Kesesuaian kuis dengan materi & 3 & Cukup baik \\
\hline $\begin{array}{l}\text { Kesesuaian tampilan background dengan usia } \\
\text { peserta didik }\end{array}$ & 3 & Cukup baik \\
\hline Kesesuaian tugas dengan materi & 3 & Cukup baik \\
\hline Kesesuaian kombinasi warna & 3 & Cukup baik \\
\hline $\begin{array}{l}\text { Keefektifan animasi untuk mendukung } \\
\text { pemahaman konsep }\end{array}$ & 3 & Cukup baik \\
\hline Media adobe flash mudah digunakan & 4 & Baik \\
\hline \multicolumn{1}{|c|}{ Jumlah } & 42 \\
\hline
\end{tabular}

Hasil penilaian kepraktisan tersebut diperoleh:

Skor rata-rata $=\frac{\text { skor total }}{\text { banyak butir }}$

Skor rata-rata $=\frac{42}{12}=3,5$

Skor rata-rata penilaian guru sebesar 3,5 yang berada dalam kategori sangat baik.

Selain dari penilaian guru, kepraktisan juga diukur dari respon siswa terhadap penerapan media pembelajaran. Data yang diperoleh dari angket respon siswa, diperoleh persentase skor respon siswa sebesar 97,7. Sesuai kriteria penilaian respon siswa, persentase respon siswa berada dalam kategori sangat positif. Berdasarkan kedua hasil tersebut maka media pembelajaran dikatakan praktis karena telah memenuhi dua indikator kepraktisan yaitu kategori baik untuk penilaian guru dan ketegori sangat positif untuk respon siswa.

Keefektifan media pembelajaran didasarkan pada hasil belajar peserta didik setelah mengikuti pembelajaran matematika pada materi translasi dan refleksi menggunakan media pembelajaran berbasis RME dengan berbantukan adobe flash. Distribusi skor hasil belajar siswa disajikan pada Tabel 6 berikut:

Tabel 6. Distribusi frekuensi skor hasil belajar siswa

\begin{tabular}{|c|c|c|c|}
\hline Interval & Frekuensi & Tuntas & Tidak tuntas \\
\hline $81-100$ & 7 & 7 & 0 \\
\hline $61-80$ & 2 & 2 & 0 \\
\hline $41-60$ & 0 & 0 & 0 \\
\hline $21-40$ & 1 & 0 & 1 \\
\hline $0-20$ & 0 & 0 & 0 \\
\hline
\end{tabular}

Dari tabel diketahui bahwa siswa yang memperoleh nilai di atas $\mathrm{KKM}=75$ berdasarkan yang berlaku di sekolah sebanyak 9 orang dan yang berada di bawah KKM sebanyak 1 orang. Selanjutnya dicari persentase ketuntasan hasil belajar menggunakan rumus:

$$
\mathrm{K}=\frac{\text { banyak siswa yang tuntas }}{\text { banyak siswa di kelas }} \times 100 \%
$$




$$
\mathrm{K}=\frac{9}{10} \times 100 \%=90 \%
$$

Berdasarkan kriteria penilaian kemampuan akademik skor persentase hasil belajar siswa tersebut berada pada interval $\mathrm{K}>80 \%$ dengan kriteria sangat tinggi, sehingga media pembelajaran dapat dikatakan efektif.

Setelah melalui tahap implementasi selanjutnya dilakukan evaluasi mengenai apa-apa saja yang kurang atau belum terpenuhi dalam media pembelajaran setelah melalui uji kevalidan, kepraktisan, dan keefektifan dengan melihat saran perbaikan dan kendala yang dihadapi siswa saat menggunakan media pembelajaran tersebut. Dari saran perbaikan dan kendala siswa peneliti merevisi media pembelajaran sesuai kebutuhan yang belum terpenuhi.

\section{KESIMPULAN}

Berdasarkan hasil penelitian yang telah dipaparkan sebelumnya, maka dapat disimpulkan bahwa media pembelajaran berbasis Realistic Mathematics Education (RME) berbantukan Adobe Flash layak digunakan. Hal ini berdasarkan dari Hasil validitas media pembelajaran berbasis Realistic Mathematics Education (RME) berbantukan adobe flash oleh dua validator dinyatakan valid. Hasil kepraktisan media pembelajaran berbasis Realistic Mathematics Education (RME) berbantukan adobe flash oleh guru matematika dan angket respon siswa dinyatakan praktis. Hasil keefektifan media media pembelajaran berbasis Realistic Mathematics Education (RME) berbantukan adobe flash dari hasil belajar siswa dinyatakan efektif.

\section{DAFTAR PUSTAKA}

Annur, M. F., \& Hermansyah. 2020. Analisis Kesulitan Mahasiswa Baru Pendidikan Matematika dalam Pembelajaran Daring pada Masa Pandemi Covid-19. Paedagoria: Jurnal Kajian, Penelitian Dan Pengembangan Kependidikan, 11(2), 195- 201.

Huda, M. 2018. Model-model pengejaran dan pembelajaran. Yogyakarta: Pustaka Pelajar

Saputri, Rinda Azmi. 2021. Sistem Pembelajaran Matematika Pada Masa Pandemi Covid-19 Di Mtsn 1 Alor, Nusa Tenggara Timur Pada Materi Bentuk Dan Operasi Pecahan Aljabar. Jurnal Pendidikan Matematika, $3(1)$.

Supriyadi, S. 2016. Adobe flash untuk mendukung pembelajaran. Jurnal Komunikasi,7(2).

Tandiling, E. 2010. Implementasi Realistic Mathematics Education (RME) di Sekolah. Jurnal Guru Membangun, 25(3).

Wibowo, E. J. 2013. Media pembelajaran interaktif matematika untuk siswa sekolah dasar kelas IV. In Seruni-Seminar Riset Unggulan Nasional Informatika dan Komputer, 2(1). 